\title{
ACTA2 wt Allele
}

National Cancer Institute

\section{Source}

National Cancer Institute. ACTA2 wt Allele. NCI Thesaurus. Code C103971.

Human ACT A2 wild-type allele is located in the vicinity of $10 q 23.3$ and is approximately 56 $\mathrm{kb}$ in length. This allele, which encodes actin, aortic smooth muscle protein, is involved in smooth muscle cell contraction. Mutations of this gene predispose patients to a variety of diffuse and diverse vascular diseases, including premature onset coronary artery disease, premature ischemic strokes, familial aortic aneurysm thoracic type 6, Moyamoya disease type 5 and multisystemic smooth muscle dysfunction syndrome. 